http://dx.doi.org/10.22319/rmcp.v9i2.4232

Nota de investigación

\title{
Detección molecular y serológica del virus de la leucosis bovina en una población de vacas Holstein, de Colombia
}

\section{Molecular and serological detection of bovine leukemia virus in a population of Holstein cows, from Colombia}

Cristina Úsuga-Monroy ${ }^{\mathrm{a} *}$

José Julián Echeverri-Zuluaga ${ }^{\mathrm{a}}$

Albeiro López-Herrera ${ }^{a}$

${ }^{a}$ Grupo de Investigación BIOGEM, Facultad de Ciencias Agrarias, Universidad Nacional de Colombia, Sede Medellín, Colombia.

*Autor de correspondencia: cusugam@unal.edu.co

\begin{abstract}
- Resumen:
La leucosis bovina enzoótica (LBE) es una enfermedad maligna, sistémica, de alta morbilidad (70 \%) y baja mortalidad, ocasionada por la infección con el virus de la leucosis bovina (BLV). La LBE afecta principalmente los bovinos de leche, disminuyendo la producción de leche de 2.5 a $5 \%$ respecto al hato; además, causa inmunosupresión, permitiendo que otros patógenos afecten la producción y reproducción de los animales. El objetivo fue determinar la presencia o ausencia del BLV a través de dos metodologías de diagnóstico: una técnica serológica (ELISA) y una técnica molecular (PCR). Se tomaron 1,000 muestras de sangre de vacas Holstein distribuidas en 10 municipios lecheros del Departamento de Antioquia. Se realizó una PCR para obtener un producto de PCR de $444 \mathrm{pb}$ correspondiente a una región altamente conservada del gen env viral, que codifica para la proteína de envoltura gp51. Se realizó un ELISA indirecta contra la proteína gp51 para estos mismos animales. La PCR detectó un número menor de muestras positivas (474) que la prueba ELISA (546). La sensibilidad de la PCR fue de $74.91 \%$ y su especificidad fue de
\end{abstract}


$85.68 \%$ respecto al ELISA. El grado de concordancia entre pruebas fue moderado (kappa=0.59). El municipio con la mayor prevalencia molecular fue Rionegro (73.91\%), mientras que la mayor seroprevalencia se registró en el municipio de El Retiro (85.19\%). El BLV ha aumentado su presencia en la región; la detección de este patógeno no solo permitirá determinar la prevalencia, sino también usar los datos obtenidos en programas de prevención y control de la enfermedad.

- Palabras clave: Virus leucosis bovina, Diagnóstico, ELISA, PCR.

\section{- Abstract:}

Enzootic bovine leukemia (EBL) is a malignant, systemic disease, high morbidity (70 \%) and low mortality, caused by infection with the bovine leukemia virus (BLV). EBL mainly affects dairy cattle; the milk production decreases of 2.5 to $5 \%$ from the herd; also cause immunosuppression allowing other pathogens affecting the production and reproduction of animals. The aim was to determine the presence or absence of BLV through two diagnostic methodologies: a serological technique (ELISA) and a molecular technique (PCR). A total of 1,000 blood samples were taken from Holstein cows distributed in 10 municipalities in Antioquia Department. A PCR was performed to obtain a 444 bp PCR product corresponding to a highly conserved region of the viral env gene, this gene encodes the envelope protein gp51. An indirect ELISA was performed against the gp51 protein for these animals. The PCR detected fewer positive samples (474) that ELISA test (546). The sensitivity of PCR was $74.91 \%$ and the specificity was $85.68 \%$, compared with the ELISA. The degree of agreement between tests was moderate (kappa=0.59). The municipality with the highest molecular prevalence was Rionegro $(73.91 \%)$, while the highest seroprevalence went to the municipality of El Retiro $(85.19 \%)$. The BLV has increased its presence in the dairy municipalities in the region; the detection of this pathogen will not only allow to determine the prevalence, it will also allow to use the data obtained in programs of prevention and control of the disease.

- Key words: Bovine leukemia virus, Diagnosis, ELISA, Nested-PCR.

Recibido 19/09/2016.

Aceptado 20/07/2017. 
El virus de la leucosis bovina (BLV) es el agente etiológico de la leucosis bovina enzoótica (LBE), pertenece a la familia Retroviridae, subfamilia Orthoretrovirinae, género Deltaretrovirus $^{(1)}$. Los animales infectados con el virus generalmente no presentan signos visibles; sin embargo, la exoftalmia es el signo más específico de la enfermedad, en la cual se produce la degeneración del tejido retro ocular y de las estructuras internas del ojo ${ }^{(2)}$. Entre el 30 al $70 \%$ los animales infectados con el BLV pueden desarrollar linfocitosis persistente (LP), la cual se caracteriza por la proliferación de linfocitos B. Sólo entre el 0.1 al $10 \%$ de los bovinos con más de tres años de infección, presentan la forma tumoral de la enfermedad o linfosarcoma (LS), en la cual los nódulos linfáticos aumentan de tamaño ${ }^{(3,4)}$. El virus está ampliamente distribuido en el mundo; en América presenta prevalencias serológicas del $83.9 \%$ en Estados Unidos ${ }^{(5)}, 10.4 \%$ en Uruguay ${ }^{(6)}$, $59 \%$ en Chile $^{(7)}$ y $41.8 \%$ en Costa Rica $^{(8)}$. En Colombia, la seroprevalencia en el 2004 fue del $44 \%{ }^{(9)}$. Para el 2014 se tomaron muestras de 8,150 bovinos en todo el territorio colombiano, de los cuales 3,840 presentaron anticuerpos contra el BLV, lo que equivale a una seroprevalencia del $42.7 \%$. De los 390 hatos evaluados, 264 presentaron infección por el virus; es decir el $67.7 \%{ }^{(10)}$. Actualmente no existe una vacuna comercial o tratamiento para LBE, por tanto, la erradicación y control de esta enfermedad se basa en el diagnóstico temprano y en la separación de los animales infectados. Las pruebas serológicas como ensayo por inmunoabsorción ligada a enzimas (ELISA) e inmunodifusión en gel de agar (AGID) son las pruebas recomendadas por la Organización Mundial de Sanidad Animal (OIE) para el diagnóstico de la infección ${ }^{(4)}$. La prueba diagnóstica AGID es ampliamente usada para la detección de anticuerpos contra los antígenos p24 o gp51 que corresponden a las proteínas de superficie del virus ${ }^{(11)}$; de igual forma la prueba ELISA también ha sido usada para detectar anticuerpos de BLV en muestras de suero, leche y remplazadores de calostro ${ }^{(12)}$. La reacción en cadena de la polimerasa (PCR) es una metodología altamente sensible de diagnóstico directo para la infección con $\mathrm{BLV}^{(13,14,15)}$. Sin embargo, los resultados de ambas pruebas de diagnóstico (ELISA y PCR) pueden variar considerablemente de acuerdo con diferentes aspectos relacionados con las técnicas empleadas, como: las condiciones fisiológicas de los animales (estado de preñez, edad), el kit empleado para la prueba serológica, el método de extracción del ADN, entre $\operatorname{otros}^{(13)}$. Los análisis de sensibilidad, especificidad y concordancia evalúan el desempeño y confiabilidad de la prueba, permitiendo dirigir con racionalidad su uso y aplicación ${ }^{(16)}$. Estos métodos cuantitativos son importantes para demostrar la eficacia de una prueba diagnóstica. El objetivo de este trabajo fue detectar el virus de leucosis bovina a través de una prueba molecular (PCR) y una prueba serológica (ELISA) en una población de vacas Holstein de lechería especializada en el departamento de Antioquia.

Esta investigación es de tipo descriptivo y sólo se evaluó la muestra poblacional en un momento de tiempo. Se tomó muestra de sangre por punción de la vena coccígea media de 1,000 vacas Holstein entre primer y quinto parto con edades de 3 a 7 años, las cuales pertenecen a 23 hatos de lechería especializada, distribuidos en 10 municipios del Departamento de Antioquia, Colombia: Subregión Valle de Aburra (Bello, Medellín), 
Subregión Norte (Belmira, Don Matías, Entrerríos, Medellín, San Pedro de los Milagros y Santa Rosa de Osos), Subregión Oriente (Rionegro, La Unión, El Retiro). Las muestras se recolectaron durante los meses de febrero a junio de 2013. Las condiciones específicas de manejo, alimentación y sanidad son variables y dependen del manejo de cada hato. Para la toma de muestras se obtuvo la aprobación por parte del comité de ética de la Universidad Nacional de Colombia (CEMED-007, 14 de mayo 2012).

La toma de muestras se hizo con una aguja calibre $18 \mathrm{G}$ con sistema al vacío vacutainer (VACUETTE®) y EDTA como anticoagulante; las muestras se homogenizaron por inversión y se trasladaron al laboratorio en condiciones de refrigeración para realizar la recolección de plasma y la extracción de ADN. Las muestras se llevaron a un tubo cónico de $15 \mathrm{ml}$ y se centrifugaron durante $4 \mathrm{~min}, 3,000 \mathrm{rpm}, 4{ }^{\circ} \mathrm{C}$; se recuperó el plasma y se almacenó a $-20{ }^{\circ} \mathrm{C}$ hasta su uso. Para obtener el ADN de los leucocitos se realizó la técnica salting out ${ }^{(17)}$ y se resuspendió en buffer TE $1 \mathrm{X}$ pH 8.0 (Tris HCl $1 \mathrm{M}$ y EDTA 0,5 M), el cual se almacenó a $4{ }^{\circ} \mathrm{C}$ hasta el momento del análisis. La calidad y cantidad del ADN obtenido se evaluó en un espectrofotómetro (NanoDrop2000®, Massachusetts-Estados Unidos) y en gel de agarosa al $1 \%$.

El método ELISA se realizó con un kit comercial (SVANOVIR® BLV gp51-Ab) de acuerdo con las instrucciones del fabricante. Se adicionaron $4 \mu \mathrm{l}$ del reactivo A (control positivo) y 4 $\mu \mathrm{l}$ del reactivo B (control negativo) en los pozos para los controles. Se adicionaron $4 \mu \mathrm{lde}$ plasma de cada muestra en los otros pozos. Se agitó la placa y se incubó a $37^{\circ} \mathrm{C}$ por $1 \mathrm{~h}$. Se lavó la placa y se adicionaron $100 \mu \mathrm{l}$ del conjugado en cada pozo y se incubó a $37{ }^{\circ} \mathrm{C}$ por 1 h. Se repitió el lavado y se adicionaron $100 \mu \mathrm{l}$ de solución sustrato, se incubó 10 min a 25 ${ }^{\circ} \mathrm{C}$. Se adicionaron $50 \mu \mathrm{l}$ de solución de parada. Se midió la densidad óptica (DO) de los controles y las muestras a $450 \mathrm{~nm}$ en un espectrofotómetro para microplacas (BioTek® ELx 800).

La detección del genoma viral por PCR se determinó a partir del ADN de las muestras de células sanguíneas (leucocitos) de las 1,000 vacas. Se amplificó una región del gen env (gp51) viral para obtener un fragmento de $444 \mathrm{pb}$ utilizando los oligonucleótidos reportados por Beier, et $a l^{(18)}$. La primera ronda de PCR se realizó en un volumen final de $25 \mu 1$ con 150 ng de ADN, $3.0 \mu \mathrm{l}$ de $10 \mathrm{mM}$ de cada oligonucleótido env 5023 (5'-TCTGTG CCAAGTCTCCCAGATA-3') y env 5608 (5'-AACAACAACCTCTGGGGAGGGT-3'), $0.4 \mathrm{mM}$ de dNTPs, 1X de tampón PCR (ThermoScientific@), $3 \mathrm{mM} \mathrm{MgCl}_{2}$ y $1 \mathrm{U}$ de Taq ADN polimerasa. En la segunda reacción de PCR se utilizó como ADN molde $5 \mu$ l del producto de PCR de la primera amplificación, con las mismas concentraciones de los otros reactivos y los oligonucleótidos env 5099 (5'-CCCACAAGGGCGGCGCCGGTTT-3') y env 5521 (5'-GCGAGGCCGGGTCCAGAGCTGG-3'), en un volumen final de $30 \mu 1$. Las reacciones para las dos PCR fueron idénticas y se realizaron en un termociclador T3 (Biometra ${ }^{\circledR}$ ) con el siguiente protocolo: desnaturalización inicial fue a $94{ }^{\circ} \mathrm{C}$ durante 5 min, 
seguido de 40 ciclos de $94{ }^{\circ} \mathrm{C}$ por $30 \mathrm{seg}, 60^{\circ} \mathrm{C}$ por 30 seg y $72{ }^{\circ} \mathrm{C}$ por 1 min, para terminar con una extensión final a $72{ }^{\circ} \mathrm{C}$ por $5 \mathrm{~min}$. El producto de la segunda reacción se verificó en un gel de agarosa al $2 \%$ en un documentador de geles (Biorad®). Como control negativo se hicieron reacciones en ausencia de ADN y como control positivo se usó inicialmente el ADN de una vaca positiva para leucosis por la técnica de ELISA; después de esto se utilizó el ADN de una de las vacas que resultó positiva para la prueba molecular. El producto de PCR definido como control positivo fue secuenciado (Macrogen®, USA) y se verificó su identidad a través del análisis de similitud nucleotídica usando el algoritmo BLAST®. Se determinó un $99 \%$ de identidad entre nuestra secuencia y la secuencia completa del virus de la leucosis bovina (LC164085.1), así como con la secuencia parcial de la glicoproteína de superficie gp51 (KU233560.1).

De acuerdo con la DO se consideraron positivas a la presencia de anticuerpos contra la proteína del BLV (gp51), aquellas muestras que obtuvieron un valor positivo porcentual (PP) mayor o igual a 15 (de acuerdo con los criterios del fabricante). Se utilizó una tabla de frecuencias para establecer la prevalencia del BLV. Se compararon los porcentajes para establecer las diferencias entre las subregiones, municipios y hatos utilizando tablas de contingencia. Se aplicó la prueba de independencia Ji-cuadrada $\left(X^{2}\right)$ y razón de momios (OR) a través de una regresión logística, para determinar la relación entre el diagnóstico de la infección por ELISA, el PCR y el lugar de origen de la muestra (hato, municipio o subregión). $\mathrm{Si}$ el resultado del OR para el municipio fue mayor a 1, hay una asociación positiva y por tanto las vacas tienen menor posibilidad de estar infectadas con el BLV. Si el resultado del OR para el municipio fue menor a 1, hay una asociación negativa y por lo tanto las vacas tienen mayor posibilidad de estar infectadas con el BLV. La significancia del OR se evaluó con Ji-cuadrada $\left(X^{2}\right)(P<0.05)$. Se utilizó una tabla de contingencia $(2 \times 2)$ para establecer los parámetros de sensibilidad y especificidad. La prueba de concordancia Kappa se utilizó para determinar la eficiencia de las dos metodologías diagnósticas. Los análisis se hicieron empleando el programa estadístico EPIDAT 3.1® y en el programa SAS® ${ }^{\circledR} .2$ para Windows (SAS InstituteInc, Cary NC, USA) todo con un nivel de confianza de 95\%.

Se obtuvieron muestras de 10 municipios dedicados a lechería especializada, distribuidos en tres subregiones del departamento de Antioquia; la Subregión Norte tenía 640 animales distribuidos en 17 hatos, la Subregión Valle de Aburrá tenía 234 animales distribuidos en tres hatos y la subregión Oriente tenía 126 animales distribuidos en tres hatos (Figura 1). La presencia o ausencia del BLV estuvo relacionada con el lugar de origen o procedencia de la muestra. Las dos metodologías de detección fueron significativas para la presencia del BLV en los diferentes hatos $\left(X^{2}=777.6420 P<0.0001\right)$, municipios $\left(X^{2}=500.5000 P<0.0001\right)$ y la subregión evaluada $\left(X^{2}=29.2811 P<0.0001\right)$. 
Figura 1: Distribución de animales y hatos en tres subregiones del departamento de Antioquia

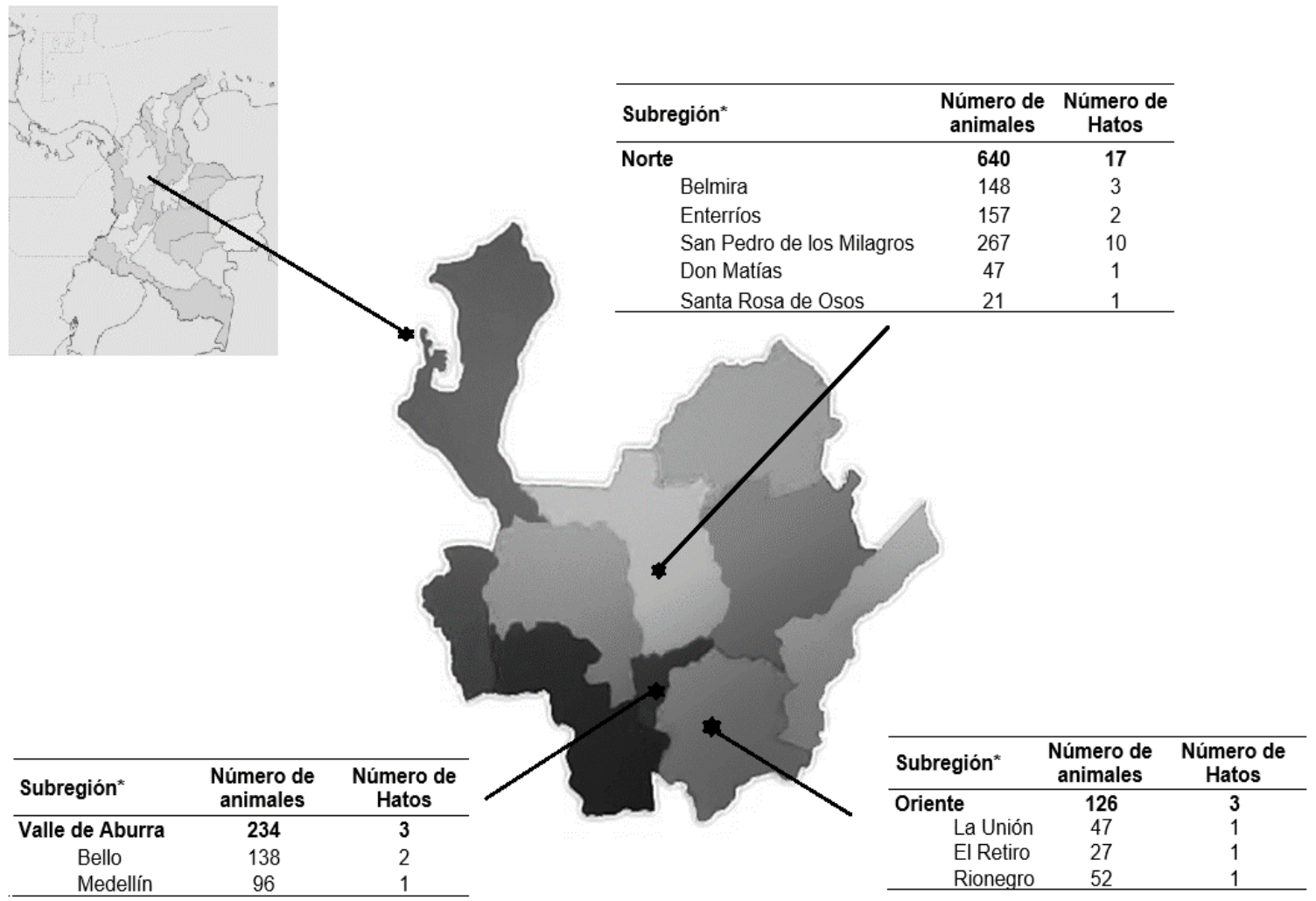

Significancia estadística para la diferencia entre los datos por subregión $* P<0.05$.

En Colombia el primer reporte de la enfermedad fue en 1957, a partir de muestras clínicas que llegaban a centros de veterinarios ${ }^{(19)}$; las primeras pruebas arrojaban seroprevalencias en ganado de leche de $24.9 \%$ para la región Andina; $14.4 \%$ en la región Caribe y $15.3 \%$ para el Piedemonte Llanero ${ }^{(19)}$. El BLV ha aumentado su prevalencia en la región Andina, en la cual se encuentra el departamento de Antioquia. La mayor prevalencia molecular para el BLV se encontró en la subregión Oriente con el $69.79 \%$ de infección, seguido de la subregión Norte con una prevalencia del $49.19 \%$ y de la subregión Valle de Aburrá con el $32.44 \%$ de infección. Estos resultados fueron similares a los encontrados por la técnica serológica ELISA, en los cuales la mayor seroprevalencia se registró en la subregión Oriente (79.17\%), seguido de la subregión Norte (53.74 \%) y la subregión Valle de Aburrá (46.67\%).

Con el uso de la PCR se logró detectar $47.6 \%$ de muestras como positivas al BLV, mientras que el ELISA logró detectar un 54.6\%. La mayor prevalencia molecular se presentó en el 
municipio de Rionegro, seguido de los municipios de El Retiro, y Medellín. La mayor prevalencia serológica se presentó en el municipio de El Retiro, seguido de los municipios de Medellín y Rionegro (Figura 2).

Figura 2: Porcentajes de infección al virus de leucosis bovina por las técnicas PCR y ELISA por municipio

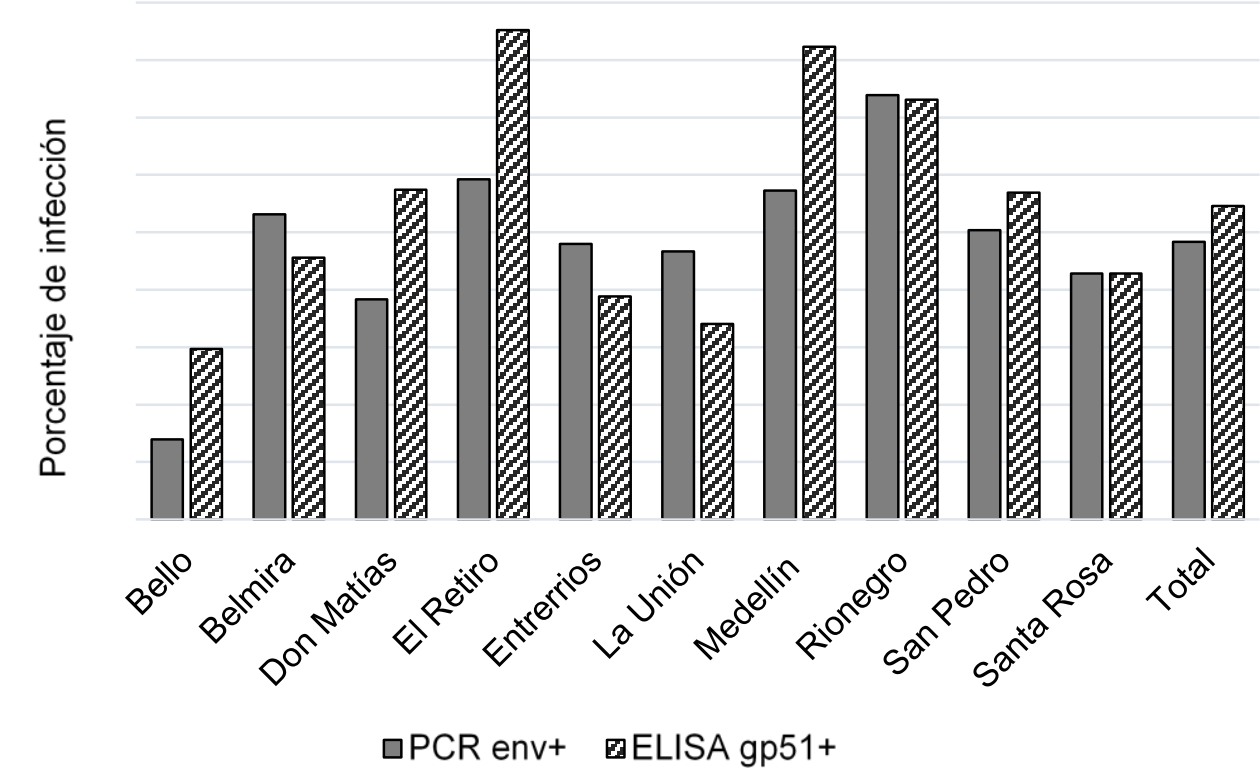

Se determinó el OR para las técnicas de detección serológica y molecular respecto a los municipios. Con el uso de la técnica ELISA se encontró que los animales que pertenecen a los municipios de Bello $(\mathrm{OR}=2.972, P<0.0001)$ y Entrerríos $(\mathrm{OR}=1.205 P<0.0001)$ tienen una menor posibilidad de presentar la infección por el BLV; mientras que los municipios de Belmira (OR=0.784, $P<0.0311$ ), El Retiro ( $\mathrm{OR}=0.617, P<0.609)$, La Unión ( $\mathrm{OR}=0.936$, $P<0.0008)$, Medellín (OR=0.669, $P<0.0001)$ y Rionegro $(\mathrm{OR}=0.399, P<0.0210)$ tienen una mayor posibilidad de presentar la infección por el BLV. Por otra parte, con el uso de la técnica PCR se encontró que los bovinos que pertenecen al municipio de Bello ( $\mathrm{OR}=2.863$, $P<0.0001)$ tienen una menor probabilidad de tener la infección por el virus, mientras que los animales que pertenecen al municipio de Rionegro $(\mathrm{OR}=0.446, P<0.0018)$ tienen una mayor probabilidad de estar infectados con el BLV (Cuadro 1). 
Cuadro 1: Razón de momios (OR) para los 10 municipios del departamento de Antioquia de acuerdo con la técnica de detección (ELISA o PCR)

\begin{tabular}{llllllllc}
\hline Municipio & \multicolumn{4}{c}{ ELISA } & \multicolumn{5}{c}{ PCR } \\
\hline Bello & OR & \multicolumn{2}{c}{ Cl (95\%) } & P> ChiSq & OR & Cl (95\%) & P> ChiSq \\
Belmira & $2.972^{* *}$ & 3.044 & 7.455 & $<0.0001$ & $2.863^{* *}$ & 3.324 & 9.277 & $<0.0001$ \\
Don Matías & $0.784^{*}$ & 0.427 & 0.864 & 0.0311 & 0.599 & 0.567 & 1.111 & 0.2238 \\
El Retiro & 1.446 & 0.493 & 1.609 & 0.9504 & 0.896 & 0.796 & 2.648 & 0.1456 \\
Entrerrios & $0.617^{*}$ & 0.072 & 0.609 & 0.0040 & 0.211 & 0.285 & 1.348 & 0.2221 \\
La Unión & $1.205^{* *}$ & 1.000 & 1.992 & $<0.0001$ & 1.904 & 0.692 & 1.376 & 0.1646 \\
Medellín & $0.936^{* *}$ & 1.400 & 5.067 & 0.0008 & 2.344 & 0.566 & 1.874 & 0.9279 \\
Rionegro & $0.669^{* *}$ & 0.151 & 0.444 & $<0.0001$ & 0.260 & 0.440 & 1.025 & 0.0723 \\
San Pedro de los Milagros & 0.851 & 0.770 & 1.334 & 0.7826 & 0.915 & 0.675 & 1.167 & 0.3693 \\
Santa Rosa de Osos & 1.196 & 0.557 & 3.143 & 0.0397 & 1.613 & 0.502 & 2.877 & 0.4501 \\
\hline
\end{tabular}

$\mathrm{Cl}=$ Intervalo de confianza, $\mathrm{ChiSq}=$ Jii cuadrada. Los municipios con mayor probabilidad de presentar la infección con el BLV* son aquellos que presentaron $O R>1$ y $P<0.05$. Los municipios con menor probabilidad de presentar la infección con el $B L V^{*}$ son aquellos que presentaron $O R<1$ y $P<0.05$ de presentar la infección con el $B L V^{*}$ son aquellos que presentaron $\mathrm{OR}>1$ y $P<0.05$. Los municipios con menor probabilidad de presentar la infección con el $B L V^{*}$ son aquellos que presentaron $\mathrm{OR}<1$ y $P<0.05$.

La prevalencia molecular para región centro del país fue 50.7 \% (37/73); además el ganado de leche presentó el mayor número de infectados (37/73) respecto al ganado de carne $(5 / 85)^{(20)}$. La prevalencia molecular de BLV para la raza Holstein en el departamento del Valle del Cauca fue del $83.3 \%{ }^{(21)}$, mientras que en 2012 se encontró un resultado similar con el $77.8 \%$ de positividad en este mismo departamento ${ }^{(22)}$. La subregión y el municipio están altamente relacionados con la presencia del virus; otros estudios también han establecido la dependencia entre el lugar de origen y la prevalencia de infección a $\mathrm{BLV}^{(21)}$. Para los hatos de Antioquia, una región de lechería especializada, este estudio determinó una prevalencia molecular del $47.6 \%$ menor a la registrada en el Valle del Cauca utilizando el mismo método diagnóstico, lo cual puede estar relacionado tanto con el lugar de origen de los animales muestreados, como con las diferencias en los sistemas de producción, ya que Antioquia cuenta con una lechería más especializada en cuanto a estructura y manejo de los animales. De acuerdo con el estudio más reciente, la seroprevalencia para Colombia es del $42.7 \%$, mientras que para el departamento de Antioquia el municipio de San Pedro presentó una seroprevalencia del $53.9 \%{ }^{(10)}$, similar a la encontrada en el presente estudio $(54.6 \%)$. La diseminación de la infección por el BLV en los hatos lecheros está relacionada con fallas en las prácticas de manejo sanitario; se ha demostrado que adecuadas prácticas iatrogénicas durante el ordeño y la vacunación (uso de una aguja por animal) son factores de protección contra la infección por el $\mathrm{BLV}^{(10)}$. 
La técnica PCR detectó 474 vacas positivas al BLV y 526 negativas al BLV. La prueba serológica ELISA detectó 546 bovinos positivos para BLV y 454 vacas negativas al BLV. Del total de vacas evaluadas 389 fueron negativas tanto por ELISA como por PCR y 409 vacas fueron positivas por ELISA y PCR. Por otra parte, 137 vacas fueron positivas por ELISA más no por PCR y 65 vacas fueron positivas por PCR más no por ELISA. El valor de concordancia entre las pruebas fue de 0.59; este valor es considerado como moderado de acuerdo a la escala de valoración propuesta por Landis y $\operatorname{Koch}^{(23)}$ (Cuadro 2); sin embargo, en un estudio por conglomerados realizado en el país, se encontró una concordancia del 0.8 o excelente ${ }^{(20)}$, la diferencia entre ambos valores puede estar dado por el lugar de origen de las muestras, el tipo de estudio y en número de animales evaluados.

Cuadro 2: Análisis de sensibilidad, especificidad y concordancia entre la PCR y el ELISA para el diagnóstico de leucosis bovina

\begin{tabular}{llll}
\hline & Valor & \multicolumn{2}{c}{ IC (95\%) } \\
\hline Sensibilidad, \% & 74.91 & 71.18 & 78.64 \\
Especificidad, \% & 85.68 & 82.35 & 89.01 \\
Valor predictivo positivo, \% & 86.29 & 83.08 & 89.49 \\
Valor predictivo negativo, \% & 73.95 & 70.11 & 77.80 \\
Índice de Youden & 0.61 & 0.56 & 0.65 \\
Concordancia: kappa & 0.59 & 0.54 & 0.64 \\
Acuerdo observado & 0.79 & & \\
Acuerdo esperado & 0.49 & & \\
\hline
\end{tabular}

La concordancia muestra que ambas técnicas de detección (PCR y ELISA) coinciden en $78 \%$ de los resultados obtenidos, es decir, que ambas técnicas detectan un número similar de animales positivos y negativos para la infección por BLV. La sensibilidad de la PCR con relación al ELISA (estándar de oro, de acuerdo con la OIE) fue $74.91 \%$ y presentó una especificidad de $85.68 \%$. Otros estudios han reportado sensibilidades del $62.7 \%{ }^{(24)}$, $84.3 \%^{(20)}$ y del $97 \%{ }^{(25)}$ para diagnóstico del BLV por estas dos metodologías (ELISA y PCR). Los resultados muestran que el valor predictivo positivo es mayor que el resultado obtenido por sensibilidad, es decir que se tiene el $86.29 \%$ de las vacas positivas por PCR realmente tienen el BLV integrado como provirus en los linfocitos B.

Aunque la PCR deja de detectar el $25.09 \%$ (137/546) de los bovinos infectados respecto al ELISA, esto puede ser por la baja carga proviral integrada en los linfocitos B de los bovinos infectados. Sin embargo, se ha demostrado que la amplificación y detección de secuencias ADN o ARN de BLV mediante PCR constituye una metodología altamente sensible de 
diagnóstico directo para la infección con $\mathrm{BLV}^{(13,14,15)}$; este método se basa en secuencias cebadoras del gen env que codifica la proteína gp51, este gen está altamente conservado y tanto el gen como el antígeno están generalmente presentes durante las diferentes fases de la infección ${ }^{(26)}$.

Las técnicas de detección PCR y ELISA presentan algunas desventajas que pueden afectar la veracidad de los resultados obtenidos. En el caso del ELISA se pueden encontrar animales con baja cantidad de inmunoglobulinas debido a que la célula blanco del virus son los linfocitos B. En otros casos la infección puede estar dada por un serotipo adaptado contra el cual no se generen anticuerpos ${ }^{(27)}$, o cuyos antígenos no sean detectados por la técnica debido a mutaciones en el epítope ${ }^{(25)}$. La técnica de detección PCR puede estar afectada por sustancias inhibidoras durante la reacción, por la cantidad de linfocitos periféricos que resultan infectados por el virus, o cuando se desarrolla una infección restringida a órganos linfoides ${ }^{(28)}$. Sin embargo, la prueba de detección ELISA es reconocida por la Organización Mundial de Sanidad Animal (OIE) para el diagnóstico del BLV ${ }^{(4)}$ debido a su simplicidad y sus ventajas prácticas y económicas ${ }^{(25)}$, por otra parte la PCR permite detectar animales infectados con el BLV antes que desarrollen una respuesta inmunológica, al igual que en animales que con baja carga proviral o con bajos títulos de anticuerpos.

El lugar de origen de la muestra (hato, municipio o subregión) está altamente relacionado con la presencia o ausencia del virus; lo que pude estar relacionado con diferentes prácticas de manejo y factores ambientales. La subregión Oriente del departamento de Antioquia presentó la prevalencia molecular y serológica más alta. A nivel de municipio las mayores prevalencias de la enfermedad se encuentran en Belmira, El Retiro, La Unión, Medellín y Rionegro; además los animales que pertenecen a estos municipios tienen una mayor probabilidad de presentar la infección por BLV.

La concordancia entre las pruebas de detección serológica y molecular evaluadas fue moderada, por tanto aunque la especificidad y sensibilidad de la técnica molecular PCR son inferiores respecto al ELISA, ambas técnicas coindicen en un $78 \%$ de los resultados. Ambas técnicas de detección pueden ser aplicadas en los hatos lecheros como herramientas importantes para conocer el estado sanitario de la enfermedad. Por otra parte, los resultados de este trabajo demuestran que más del $50 \%$ de los animales evaluados presentaron títulos contra el BLV y el provirus integrado en su genoma; este resultado presenta una visión global del nivel de infección por BLV en los hatos de lechería especializada del departamento de Antioquia. 


\section{Agradecimientos}

A la Dirección de Investigación de la Universidad Nacional de Colombia sede Medellín por su financiación para el desarrollo de esta investigación, proyecto código Quipu 201010012967.

\section{- Literatura citada:}

1. Wu D, Murakami K, Morooka A, Jin H, Inoshim Y, Sentsui H. In vivo transcription of bovine leukemia virus and bovine immunodeficiency-like virus. Virus Res 2003;97(2):81-87.

2. Malatestinic A. Bilateral exophthalmos in a Holstein cow with lymphosarcoma. Can Vet J 2003;44(8):664-666.

3. Dees C, Godfrey V, Schultz R, Travis C. Wild type p53 reduces the size of tumors caused by bovine leukemia virus infected cell. Cancer Lett 1996;101(1):115-122.

4. OIE, Organización Mundial de Salud Animal. Manual de las pruebas de diagnóstico y de las vacunas para los animales terrestres 2012. http://www.oie.int/fileadmin/ Home/esp/Health_standards/tahm/2.04.10_Leucosis_bovina_enzo\%C3\%B3tica.pdf. Consultado 12 Jul, 2016.

5. USDA. United States Department of Agriculture. Bovine Leukosis Virus (BLV) on U.S. Dairy Operations, 2007. https://www.aphis.usda.gov/animal_health/nahms/dairy/ downloads/dairy07/Dairy07_is_BLV.pdf. Consultado 12 Jul, 2016.

6. Furtado A, Rosadilla D, Franco G, Piaggio J, Puentes R. Leucosis bovina enzoótica en cuencas lecheras de productores familiares del Uruguay. Veterinaria 2013;49(191):2937.

7. Felmer R, Zúñiga J, López A, Miranda H. Prevalencia y distribución espacial de brucelosis, leucosis bovina, diarrea viral bovina y rinotraqueítis infecciosa bovina a partir del análisis ELISA de estanques prediales en lecherías de la IX Región, Chile. Arch Med Vet 2009;4(1):17-26. 
8. Romero J, Dávila G, Beita G, Dolz G. Efecto del estatus serológico al virus de la leucosis enzoótica bovina (BLV) sobre la producción de leche en hatos lecheros de Costa Rica. Rev Ciencias Veterinarias 2012;30(2):43-55.

9. FEDEGAN, Federación Colombiana de Ganaderos. El consumo de sal mineralizada en el sector bovino. Bajo consumo, baja productividad. 2014. http://www.fedegan. org.co/carta-fedegan-142-el-consumo-de-sal-mineralizada-en-el-sector-bovino-bajoconsumo-baja-productividad. Consultado 12 Jul, 2016.

10. Ortega D, Sánchez A, Tobón J, Chaparro Y, Cortés S, Gutiérrez M. Seroprevalence and risk factors associated with bovine leukemia virus in Colombia. J Vet Med Anim Health 2016;8(5):35-43.

11. Mohammadabadi M, Soflaei M, Mostafavi H, Honarmand M. Using PCR for early diagnosis of bovine leukemia virus infection in some native cattle. Genet Mol Res 2011;10(4):2658-2663.

12. Choudhury B, Finnegan C, Phillips A, Horigan M, Pollard T, Steinbach F. Detection of Bovine Leukaemia Virus antibodies and proviral DNA in calostrum replacers. Transbound Emerg Dis 2015;62(5):e60-e61.

13. Fechner H, Kurg A, Geue L, Blankestein P, Mewes G, Ebner D, et al. Evaluation of polymerase chain reaction (PCR) application in diagnosis of bovine leukaemia virus (BLV) infection in naturally infected cattle. Zentralbl Veterinarmed B 1996;43(10):621630.

14. Rubianes A, Oriani D. Reacción en cadena de la polimerasa (PCR) como herramienta diagnóstica de Leucosis enzoótica bovina. Ciencia Veterinaria. Facultad de Ciencias Veterinarias, 2000. 103-109. http://www.biblioteca.unlpam.edu.ar/pubpdf/revet/ n02a14alvarez.pdf. Consultado 12 Jul, 2016.

15. Rola M, Kuzmak J. The detection of bovine leukemia virus proviral DNA by PCRELISA. J Virol Methods 2002;9(1-2):33-40.

16. Cortés-Reyes E, Rubio-Romero J. Métodos estadísticos de evaluación de la concordancia y la reproductibilidad de pruebas diagnósticas. Rev Colomb Obstet Ginecol 2010;61(3):247-255.

17. Miller S, Dykes D, Polesky H. A simple salting out procedure for extracting DNA from human nucleated cells. Nucleic Acids Res 1988;16(3):1215.

18. Beier D, Blankenstain P, Marquard O, Kuzmak J. Identification of different BLV provirus isolates by PCR, RFLPA and DNA sequencing. Berl Munch Tierarztl Wochenschr 2001;114(7-8):252-256. 
19. Mariño O. Situación de la investigación en leucosis bovina en Colombia. Rev ACOVEZ $1984 ; 8(27): 22-26$.

20. Meza-Barreto G, Sanjuanelo-Corredor D, Gallego-Marín M. Detección molecular del virus de la leucosis bovina: un estudio por conglomerados en Colombia. Rev Cienc Agri 2016;13(2):47-55.

21. Hernández Y, Posso M, Benavides J, Muñoz J, Giovambattista G, Álvarez L. Detección del virus de la leucosis bovina en ganado criollo colombiano mediante PCR-anidado. Acta Agronómica 2011;60(4):312-318.

22. Cadavid L. Impacto del virus de la leucosis bovina en la producción de leche. [tesis maestría]. Colombia, Palmira. Universidad Nacional de Colombia; 2012. http://www.bdigital.unal.edu.co/9308/1/lascarioartemocadavidgutierrez.2012.pdf.

Consultado 20 Jul, 2016.

23. Landis J, Koch, G. The measurement of observer agreement for categorical data. Biometrics 1977;33:159-174.

24. Nagy D, Tyler J, Kleiboeker S, Stoker A. Use of a polymerase chain reaction assay to detect bovine leukosis virus in dairy cattle. J Am Vet Med Assoc 2003;222(7):983-985.

25. Felmer R, Zúñiga J, Recabal M. Estudio comparativo de un PCR anidado, ELISA y AGID en la detección del virus de la leucosis bovina en muestras de suero, sangre y leche. Arch Med Vet 2006;38(2):137-141.

26. Baruta D, Ardoino S, Brandan J, Sosa R, Mariani E, Albrecth E. Leucosis Bovina Enzoótica. Ciencia Veterinaria 2011;13(1):9-14.

27. Kuckleburg C, Chase C, Nelson E, Marras S, Dammen M, Christopher-Hennings J. Detection of bovine leukemia virus in blood and milk by nested and real-time polymerase chain reactions. J Vet Diagn Invest 2003;15(1):72-76.

28. Klintevall K, Bagalli-Pordany A, Naslud K, Belak S. Bovine Leukemia Virus: rapid detection of proviral DNA by nested PCR in blood and organs of experimentally infected calves. Vet Microbiol 1994;3(2-3):191-204. 